Inflammation, Vol. 13, No. 5, 1989

\title{
INTERACTION OF MAMMALIAN CELLS WITH POLYMORPHONUCLEAR LEUKOCYTES: Relative Sensitivity to Monolayer Disruption and Killing ${ }^{1}$
}

\author{
ISAAC GINSBURG, ${ }^{2}$ DOUGLAS F. GIBBS, ${ }^{3}$ \\ and JAMES VARANI ${ }^{3}$ \\ ${ }^{2}$ Department of Oral Biology, Hebrew University-Hadassah \\ School of Dental Medicine, Jerusalem, Israel \\ ${ }^{3}$ Department of Pathology, The University of Michigan \\ Medical School, Ann Arbor, Michigan.
}

\begin{abstract}
Absiract-Monolayers of murine fibrosarcoma cells that had been treated either with histone-opsonized streptococci, histone-opsonized Candida globerata, or lipoteichoic acid-anti-lipoteichoic acid complexes underwent disruption when incubated with human polymorphonuclear leukocytes (PMNs). Although the architecture of the monolayers was destroyed, the target cells were not killed. The destruction of the monolayers was totally inhibited by proteinase inhibitors, suggesting that the detachment of the cells from the monolayers and aggregation in suspension were induced by proteinases released from the activated PMNs. Monolayers of normal endothelial cells and fibroblasts were much more resistant to the monolayer-disrupting effects of the PMNs than were the fibrosarcoma cells. Although the fibrosarcoma cells were resistant to killing by PMNs, killing was promoted by the addition of sodium azide (a catalase inhibitor). This suggests that the failure of the PMNs to kill the target cells was due to catalase inhibition of the hydrogen peroxide produced by the activated PMNs. Target cell killing that occurred in the presence of sodium azide was reduced by the addition of a "cocktail" containing methionine, histidine, and deferoxamine mesylate, suggesting that hydroxyl radicals but not myeloperoxidase-catalayzed products were responsible for cell killing. The relative ease with which the murine fibtosatcoma cells can be released from their substratum by the action of PMNs, coupled with their insensitivity to PMN-mediated killing, may explain why the presence of large numbers of PMNs at the site of tumors produced in experimental animals by the fibrosarcoma cells is associated with an unfavorable outcome.
\end{abstract}

'Supported by a research grant from Dr. S.M. Robbins, Cleveland, Ohio; by research grant IM-432 from the American Cancer Society and by grants HL-28872, HL-37963 and GM-29501 from the National Institutes of Health, Bethesda, MD. Isaac Ginsburg was a visiting professor at the Department of Pathology in 1987-1988. 


\section{INTRODUCTION}

Recent studies from our laboratories have described the roles played by cationic polyelectrolytes as opsonins for phagocytosis by both "professional" and "nonprofessional" phagocytes $(1,2)$, as activators of the respiratory burst in human neutrophils (PMNs) (3-6), as activators of bacteriolysis in gram-positive bacteria $(7-10)$, and as modulators of tissue damage induced by immune complexes (11). More recently, we have shown that murine fibrosarcoma cells that had injested polyelectrolyte-opsonized Candida species (C. albicans or C. globerata) grew much faster and metastasized much earlier than control tumor cells when injected into footpads of mice (12). Although the mechanism by which the internalized yeast cells affected tumor cell growth in vivo is not fully understood, we invariably observed that the growth of the tumors in the footpads was accompanied by a substantial influx of PMNs. Since activated PMNs secrete proteolytic enzymes, PMN proteases might facilitate the detachment of cells from the bulk of the fumor, accounting for the rapid dissemination of the tumor cells.

In addition to their potent proteolytic enzymes, PMNs also produce toxic oxygen radicals upon activation, and these oxygen radicals are capable of killing many, although not all, cells (13). The proteolytic enzyme-mediated and oxygen radical-mediated effects of PMNs on target cells depend on close apposition between target and effector cells. PMN adherence to potential target cells may be mediated by specific recognition structures on the surface of target and effector cells $(14,15)$. Adhesion may also be mediated by the Fc portion of antibodies directed against target cell membrane antigens or against microbial antigens such as lipoteichoic acid (LTA) or lipopolysaccharide, which intercalate into the plasma membranes of mammalian cells via their lipid moieties ( 16 , 17). In the present study we have examined how microbial cells and their cell constituents can influence the interaction of PMNs with potential targets. The present communication shows that intact cationized microbial cells avidly adhere to mammalian cells in culture. These microbial products induce PMN adhesion to the target cells and simultaneously serve to activate the PMNs. Depending on the target cell type and the conditions under which the interaction occurs, the PMNs may disrupt the architecture of the monolayer without killing the cells or kill the target cells and disrupt the monolayer.

\section{MATERIALS AND METHODS}

Cells. A line of murine fibrosarcoma cells was used in these studies. These cells were isolated from a 3-methylcholanthrene-induced tumor in a C57B1/6 mouse as described (18). They were grown in monolayer culture using RPMI 1640 medium supplemented with $10 \%$ fetal bovine 
serum, 100 units/ml of penicillin, and $100 \mu \mathrm{g} / \mathrm{ml}$ of streptomycin as culture medium. Growth was at $37^{\circ} \mathrm{C}$ and $5 \% \mathrm{CO}_{2}$. The tumor cells were subcultured by trypsinization as necessary. In certain experiments, rat pulmonary artery endothelial cells and rat pulmonary fibroblasts were used in place of the murine fibrosarcoma cells. The endothelial cells were isolated as described previously (19). They grew with a "cobblestone" morphology, evident at both the light and electron microscopic levels, contained high levels of angiotensin-converting enzyme, and reacted strongly with antibodies to factor VIII. The endothelial cells were grown in minimal essential medium of Eagle with Earle's salts (MEM) supplemented with $10 \%$ fetal bovine serum and antibiotics. Growth was at $37^{\circ} \mathrm{C}$ and $5 \% \mathrm{CO}_{2}$. They were subcultured by scraping with a rubber policeman upon reaching confluence. The fibroblasts were isolated as described previously (20) and were grown under the same conditions as the endothelial cells. The fibroblasts were subcultured by trypsinization as required.

Microorganisms. Group A streptococci (strain C203S, protein M negative) were oblained from the stock of the Department of Oral Biology, Hebrew University. C. globerata was obtained from Dr. Carl Pierson, Clinical Microbiology Laboratory, University of Michigan Hospital. The streptococci were cultivated in brain-heart infusion broth, and the $C$. globerata were cultured on trypticase soy agar plates. Microbial suspensions were adjusted to contain approximately $10^{9} \mathrm{col}$ ony forming units/rnl.

Lipoteichoic Acid (LTA). LTA was isolated from gtoup A streptococci and purified according to Fischer et al. (21). Rabbit anti-group A streptococcal globulin containing 39,000 hemagglutinating units/ml of anti-LTA activity was employed $(16,22)$. We are indebted to Makor ChemicalsSigma Israel for the generous supply of the LTA and anti-LTA-globulin.

Opsonization of Particles with Cationic Agents. Group A streptococci $\left(10^{\%} / \mathrm{ml}\right)$ and heatkilled $C$. globerata $\left(10^{9} / \mathrm{ml}\right)$ were treated for $30 \mathrm{~min}$ at $37^{\circ} \mathrm{C}$ with $1 \mathrm{mg}$ of nuclear histone (type II-A, Sigma Chemical Co., St. Louis, Missouri). The cells were then washed several times in saline to remove unbound ligand and the polycation-opsonized microbial cells were kept at $4^{\circ} \mathrm{C}$ for up to two weeks. The cationized particles were added to the monolayers of the target cells at a ratio of 10-50: 1 (see below).

PMNs. Human PMNs were isolated from heparinized venous blood by dextran sedimentation followed by density-gradient centrifugation through Ficoll-Hypaque $(4,5)$. The cells were

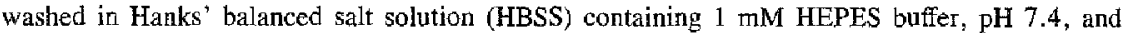
kept on ice until use. Such cells retained their full superoxide anion $\left(\mathrm{O}_{2}{ }^{-} \cdot\right)$ generating capacity for up to $6 \mathrm{~h}$.

Leukocyte Extracts. PMNs that had been separated from the blood of normal donors were subjected to five cycles of freezing and thawing. The supernatant fluids were separated from debris by high-speed centrifugation and lyophilized. Such preparations contained the bulk of both acid and neutral lysosomal hydrolases.

Measurement of $\mathrm{O}_{2}{ }^{-} \cdot$ Production. $\mathrm{O}_{2}{ }^{-} \cdot$ generation was measured by the superoxide dismutase-inhibitable reduction of ferricytochrome $\mathrm{C}$ according to the method of Babior, et al. (23). The reaction mixture consisted of $1 \times 10^{5}$ unstimulated or stimulated PMNs and $80 \mu \mathrm{m}$ ferricytochrome C (obtained from Signa) in $0.9 \mathrm{ml}$ of HBSS. To one set of duplicate tubes was added $0.1 \mathrm{ml}$ of HBSS while 85 units of SOD was added to the other set. The tubes were incubated for $60 \mathrm{~min}$ at $37^{\circ} \mathrm{C}$ after which the total volume was brought to $1.8 \mathrm{ml}$. The tubes were centrifuged and the absorbance of the supernatant fluids at $550 \mathrm{~nm}$ was determined. The difference in absorbance between the presence and absence of SOD was determined, and the amount of ferricytochrome $C$ reduced was calculated based on an extinction coefficient of $18.5 \mathrm{~cm}^{-1} \mathrm{mM}^{-1}$ for ferricytochrome $\mathrm{C}$.

Measurement of Hydrogen Peroxide $\left(\mathrm{H}_{2} \mathrm{O}_{2}\right)$ Production. $\mathrm{H}_{2} \mathrm{O}_{2}$ generation was determined in the presence of $1 \mathrm{mM}$ sodium azide by the method of Therman et al. (24). PMNs $\left(2 \times 10^{6}\right)$ were incubated for $1 \mathrm{~h}$ in HBSS. At the end of the incubation period, the reaction was terminated by the addition of $0.1 \mathrm{ml}$ of trichloroacetic acid $(50 \% \mathrm{w} / \mathrm{v})$. The samples were centrifuged for 10 
min at $500 \mathrm{~g}$, and $10 \mathrm{mM}$ ferrous ammonirum sulfate $(0.2 \mathrm{ml})$ and $2.5 \mathrm{mM}$ potassium thiocyanate $(0.1 \mathrm{ml})$ were added to the supernatant fluid. The absorption of the ferrithiocyanate complex was measured at $480 \mathrm{~nm}$ and compared with a standard curve generated from dilutions of a reference solution of $\mathrm{H}_{2} \mathrm{O}_{2}$.

Measurement of Proteolytic Enzyme Activity. Hydtolysis of hemoglobin by unstimulated and stimulated PMNs was used as a measure of proteolytic enzyme activity (25). Bovine hemoglobin was prepared as a $1 \mathrm{mg} / \mathrm{ml}$ solution in HBSS, and $0.5 \mathrm{ml}$ of the hemoglobin solution was incubated with $5 \times 10^{5}$ PMNs in $0.1 \mathrm{ml}$ for $18 \mathrm{~h}$ at $37^{\circ} \mathrm{C}$. After incubation, $0.25 \mathrm{ml}$ of $40 \%$ trichloroacetic acid was added to precipitate the protein. The tubes were left at room temperature for an additional $15 \mathrm{~min}$ and then were centrifuged at $2000 \mathrm{rpm}$ for $20 \mathrm{~min}$. Following this, 0.5 $\mathrm{ml}$ of the supernatant fluid was removed from each tube and the amount of proteolytic fragments determined by the Lowry method (26), in comparison with a bovine serum albumin standard.

Cytotoxicity Assay. Cytotoxicity was measured using a ${ }^{51} \mathrm{Cr}$-release assay. The target cells were seeded into the wells of a 24-well culture dish at $1.0 \times 10^{5}$ cells per well in $1 \mathrm{ml}$ of culture medium. Each well received $10 \mu \mathrm{Ci}$ of $\left[{ }^{3 i} \mathrm{Cr}\right] \mathrm{NaCrO}_{4}$ (New England Nuclear, Boston, Massachusetts). The cells then were incubated for $18 \mathrm{~h}$, after which they were washed twice to remove unincorporated radioactivity. Suspensions of PMNs in HBSS supplemented with $0.5 \%$ bovine serum albumin then were added to duplicate or triplicate wells to give various effector-to-target ratios in a final volume of $1.0 \mathrm{ml}$. After an additional incubation at $37^{\circ} \mathrm{C}$ for $18 \mathrm{~h}, 0.9 \mathrm{ml}$ of supernatant was removed from each well and centrifuged. The supernatant $(0.5 \mathrm{ml})$ was aspirated and counted in a $\gamma$-scintillation counter to determine ${ }^{51} \mathrm{Cr}$ release. Spontaneous release was obtained from wells receiving medium only and total release was obtained from wells receiving $0.2 \%$ Triton X-100. The spontaneous release never exceeded $20 \%$ of the total release and in most experiments ranged between 5 and $15 \%$ of the total release. The percentage of cytotoxicity was calculated by the following formula:

$$
\% \text { Cytotoxicity }=\frac{\text { Experimental release }- \text { spontaneous release }}{\text { Total release }- \text { spontaneous release }}
$$

\section{RESULTS}

Interaction of Opsonized Microorganisms or LTA with Mammalian Cells. Histone-opsonized C. globerta and group A streptococci were added to monolayers of murine fibrosarcoma cells. Adhesion of the microbial cells to the tumor cell monolayers was evident within $5 \mathrm{~min}$ by phase-contrast microscopy. Virtually $100 \%$ of the microbial particles were firmly attached to the tumor cells. There was no attachment to the surface of the culture dish. Tumor cell phagocytosis of the microbial particles could be seen but was difficult to quantitate by phase-contrast microscopy. In order to accurately assess phagocytosis, tumor cells monolayers were fixed in glutaraldehyde at various time points after addition of the microbial cells. Thick sections were cut perpendicular to the plane of the culture dish, and the percentage of tumor cells that had phagocytosed the microbial cells was determined. Figure 1 (upper left) shows the percentage of cells with injested $C$. globerta particles as a function of time after addition of the microbial cells. Figure 1 (upper right) shows the distribution of 

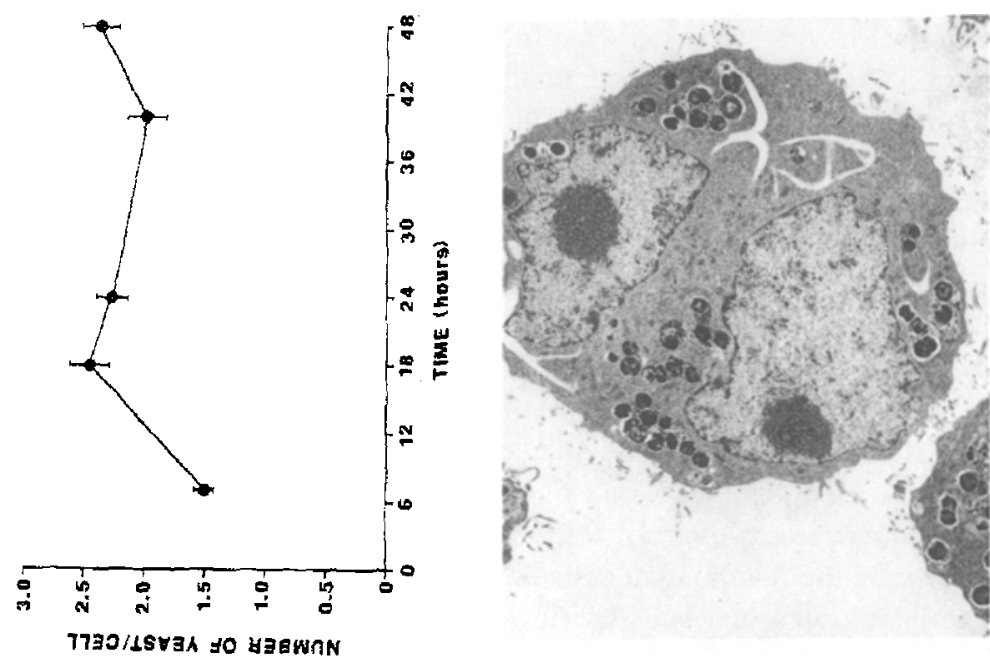

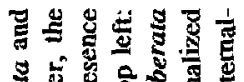

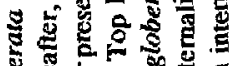

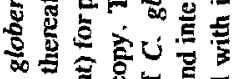
U 解

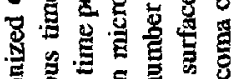

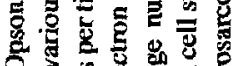

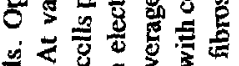

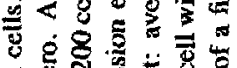
象 尊

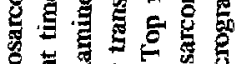
和歌各

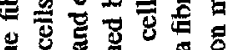

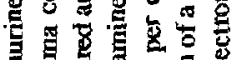

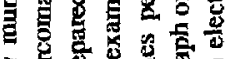

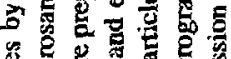

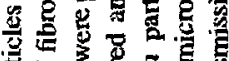
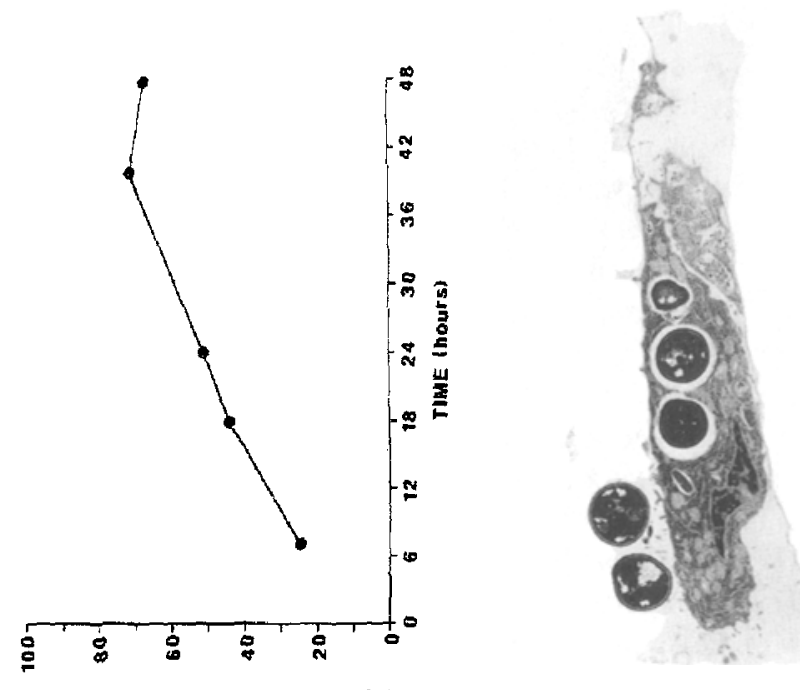

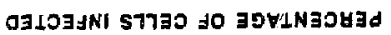
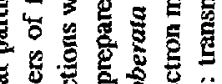

ธ్

等

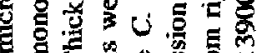

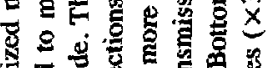

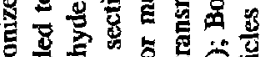

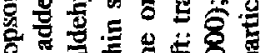
\&

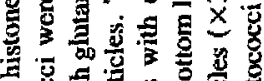

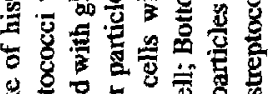

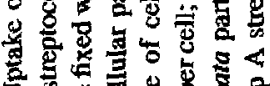
क्टे के

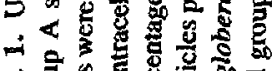

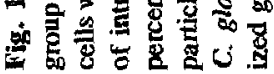


microbial particles among the tumor cells. An electron micrograph showing a fibrosarcoma cell with C. globerta particles on the cell surface and inside the cell is shown in Figure 1 (lower left). Opsonized group A streptococci were handled by the tumor cells in a similar manner to $C$. globerta, the major difference being that phagocytosis of these smaller particles occurred more rapidly and the average number of microbial particles injested per cell was higher. An electron micrograph showing a fibrosarcoma cell with injested streptococci is shown in Figure 1 (lower right).

The capacity to bind opsonized microbial cells was not limited to the murine fibrosarcoma cells. Similar results were obtained with rat endothelial cells and fibroblasts. With both cell types, the adherence of the microorganisms occurred as rapidly as with the murine fibrosarcoma cells. The kinetics of phagocytosis by the normal fibroblasts was similar to those shown in Figure 1 with the fibrosarcoma cells. However, the endothelial cells injested the microbial particles much more rapidly than either the fibroblasts or fibrosarcoma cells. Evidence of phagocytosis by these cells could be seen as early as 20 min after addition of the microbial cells to the monolayers (not shown). In contrast to these results with opsonized microbial cells, we rarely detected binding and phagocytosis of unopsonized particles by the mammalian cells in culture.

In addition to intact microbial cells, purified LTA from group A streptococci also rapidly bound to the surface of mammalian cells. Although we could detect no change in the morphology of the mammalian cells following the binding of LTA, the presence of LTA on the cell surface facilitated subsequent interactions with PMNs (see following section).

Interaction of PMNs with Mammalian Cells after Treatment with Opsonized Microbial Particles or LTA. PMNs were added to monolayers of untreated fibrosarcoma cells or to monolayers of cells after treatment with intact opsonized microbial particles or with LTA, followed by the addition of anti-LTA antibodies. PMNs rapidly adhered to tumor cell monolayers with surface-bound microorganisms or with cell-bound LTA-anti-LTA complexes. They did not bind to control monolayers or to monolayers in the presence of unopsonized microbial cells. The first sign of damage to the fibrosarcoma monolayers that had been precoated with opsonized microorganisms and further treated with PMNs occurred after 2-3 h. The cells began to round up and detach from the substrate. By $18 \mathrm{~h}$, most of the tumor cells had detached and were present as large clusters in suspension. The appearance of control and treated fibrosarcoma cells is shown in Figure 2. Monolayers treated with PMNs in the absence of microbial cells or in the presence of unopsonized microbial particles did not show any substantial changes. Similar but much less extensive alterations in the architecture of endothelial cell or fibroblast monolayers were observed after the same treatment. Despite the extensive morphological changes induced in the target cell monolayers by mixtures of opsonized particles and PMNs, the target 

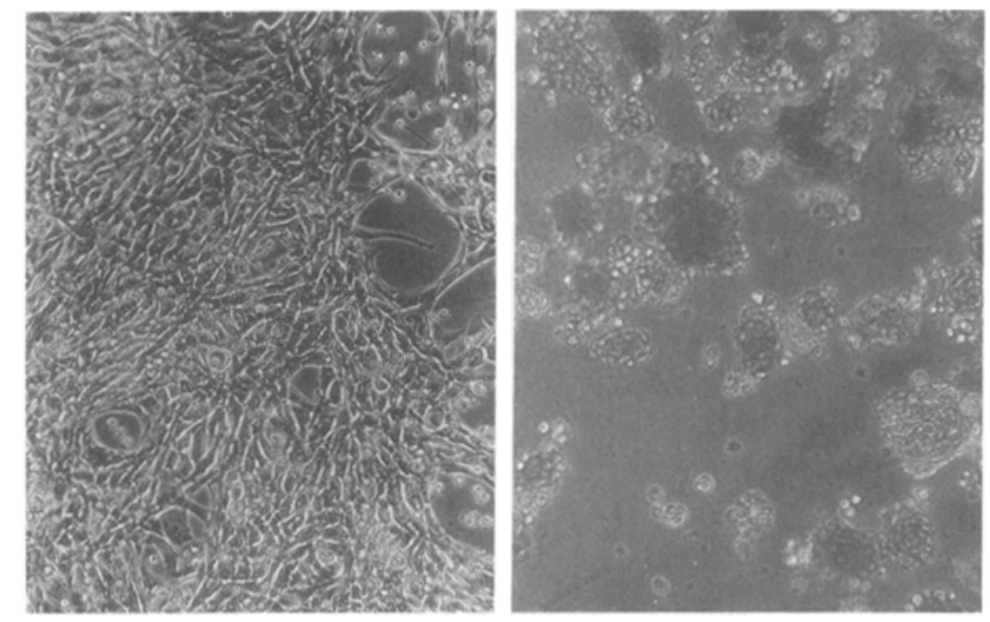

Fig. 2. Left: control fibrosarcoma monolayer $(\times 300)$. Right: aggregates of fibrosarcoma cells in suspension $18 \mathrm{~h}$ after incubation with opsonized group A streptococci and PMNs $(\times 300)$.

cells were not killed. This was demonstrated by a lack of ${ }^{51} \mathrm{Cr}$ release from prelabeled cells (see following section). Since the detachment of the fibrosarcoma cells from the monolayer after exposure to activated PMNs resembled the effects of exposure to proteolytic enzymes, monolayers of fibrosarcoma cells were treated with opsonized microbial cells and PMNs in the presence of SBTI $(10-100 \mu \mathrm{g})$. The presence of SBTI totally inhibited cell rounding and detachment from the monolayers. In other experiments it was found that PMN extracts, containing the bulk of the leukocyte proteases, were able to substitute for viable PMNs in inducing disruption of the tumor cell monolayer. Disruption of the monolayer by PMN extracts was also totally inhibited in the presence of SBTI.

PMN-induced disruption of the tumor cell monolayer was also seen after exposure of the target cell monolayer to LTA. For LTA to function as a bridge between the target cells and PMNs required sequential treatment of the target cells with LTA and antibodies to LTA. Thus, PMN binding to the target cells in this case appeared to be mediated through immune complexes on the target cell surface. This interaction has been described in detail in recent studies (16, 17, 27). PMN binding to the fibrosarcoma cells through LTA-anti-LTA complexes had the same effect on the target cells as binding through opsonized microbial particles, i.e., the monolayers were completely disrupted without a significant amount of cell killing (not shown). In a similar manner, PMNs bound to endothelial cells or fibroblasts through LTA-anti-LTA complexes induced disruption of these monolayers without inducing a substantial loss of viability. As was observed with opsonized microorganisms, the degree of disruption of 
the endothelial cell and fibroblast monolayers was less than the degree observed with the fibrosarcoma cell monolayers.

PMN-Mediated Killing of Mammalian Cells following Treatment with Opsonized Microbial Cells and LTA-anti-LTA Complexes. In previous studies we (28-30) and others (31-33) have demonstrated that activated PMNs are cytotoxic to endothelial cells and that killing is $\mathrm{H}_{2} \mathrm{O}_{2}$-dependent. Conditions required for killing included close contact between the effector and target cells, activation of the effector cells with a stimulus that induces high levels of $\mathrm{O}_{2}{ }^{-}$. generation, and incubation in a buffer that does not include large amounts of oxygen radical scavengers. Even though these conditions were met in the present study, the fibrosarcoma cells were still resistant to killing by the PMNs. The failure of the PMNs to effectively kill the murine fibrosarcoma cells was probably due, in part, to the presence of an effective antioxidant barrier (i.e., catalase) associated with the target and/or effector cells. Experiments were conducted in which fibrosarcoma cells or PMNs were examined for ability to inactivate $\mathrm{H}_{2} \mathrm{O}_{2}$. Both cell types were capable of inactivating $\mathrm{H}_{2} \mathrm{O}_{2}$. PMNs were much more active than the tumor cells (Figure 3 ). Pretreatment of the cells with sodium azide destroyed the $\mathrm{H}_{2} \mathrm{O}_{2}$-inhibitory activities of both PMNs and tumor cells. In further experiments, sodium azide was added to fibrosarcoma cell mon-

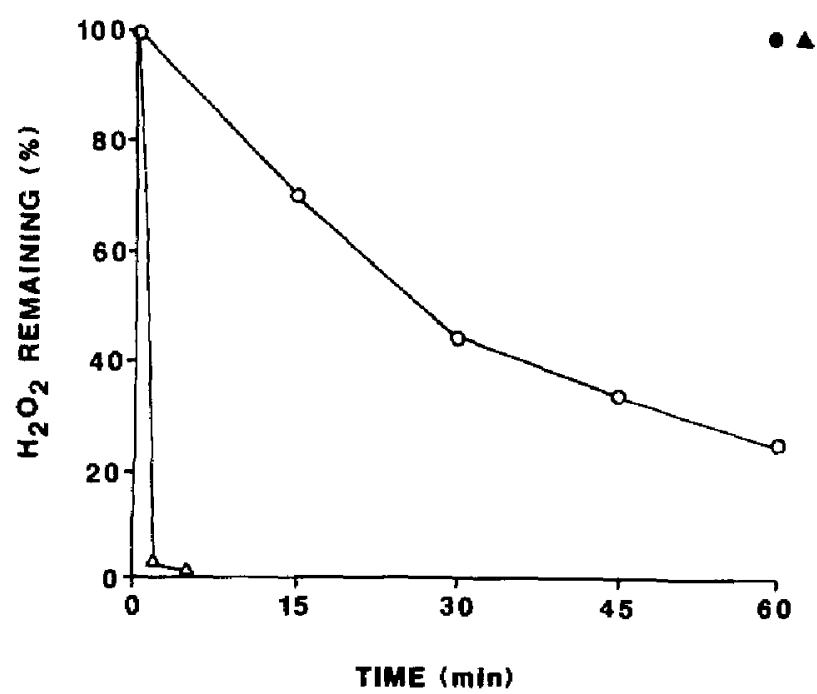

Fig. 3. Destruction of $\mathrm{H}_{2} \mathrm{O}_{2}$ by PMNs and fibrosarcoma cells. PMNs $\left(2 \times 10^{6} / \mathrm{ml}\right)(\triangle)$, PMNs $\left(2 \times 10^{6} / \mathrm{ml}\right)$ in the presence of $1 \mu \mathrm{M}$ sodium azide $(\Lambda)$, fibrosarcoma cells $\left(5 \times 10^{5} / \mathrm{mb}\right)(\mathrm{O})$ and fibrosarcoma cells $\left(5 \times 10^{5} / \mathrm{m}\right)$ in the presence of $1 \mu \mathrm{M}$ sodium azide (-) were mixed with 100 nmols of $\mathrm{H}_{2} \mathrm{O}_{2}$. After incubation for various time periods at $37^{\circ} \mathrm{C}$, the amount of $\mathrm{H}_{2} \mathrm{O}_{2}$ remaining was measured. 
olayers along with PMNs. When the PMNs were not activated (i.e., in the absence of preopsonization of the target cells), the presence of sodium azide had no effect on the integrity of the monolayer or on the viability of the cells. However, when fibrosarcoma cells that had been pretreated with opsonized microorganisms were exposed to PMNs in the presence of sodium azide, there was a dramatic increase in killing (Figure 4). The same treatment also greatly potentiated killing of endothelial cells (Figure 5) and normal fibroblasts (not shown). Sodium azide also facilitated neutrophil killing of fibrosarcoma cells treated with LTA-anti-LTA (Figure 4).

Finally, experiments were conducted in which fibrosarcoma cell monolayers were treated with opsonized microorganisms and then exposed to PMNs in the presence of sodium azide and a "cocktail" of oxygen radical inhibitors including $1 \mathrm{mM}$ histidine, $1 \mathrm{mM}$ methionine, and $1 \mathrm{mM}$ deferoxamine mesylate. These inhibitors have been previously shown to inhibit the formation of

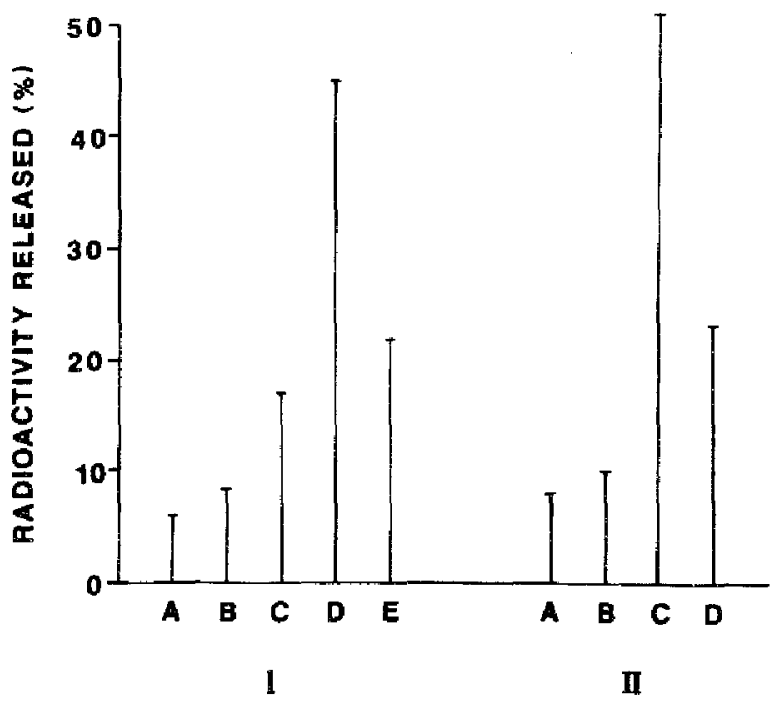

Fig. 4. PMN killing of murine fibrosarcoma cells. Fibrosarcoma cells were labeled with ${ }^{51} \mathrm{Cr}$ and examined for sensitivity to killing by PMNs as described in Materials and Methods. I. Fibrosarcoma cells were treated with A, unopsonized streptococci; B, histone-opsonized streptococci; $C$, histone-opsonized streptococci and PMNs; D, histone-opsonized streptococci, PMNs, and $1 \mu \mathrm{M}$ sodium azide; E, histone-opsonized streptococci, PMNs, $1 \mu \mathrm{M}$ sodium azide, and a "cocktail" of inhibitors including $1 \mathrm{mM}$ histidine, $1 \mathrm{mM}$ methionine, and $1 \mathrm{mM}$ deferoxamine mesylate. II. Fibrosarcoma cells were treated with A, LTA-anti-LTA complexes; B, LTA-anti-LTA complexes and PMNs; C, LTA-anti-LTA complexes, PMNs, and $1 \mu \mathrm{M}$ sodium azide; and D, LTA-antiLTA complexes, PMNs, $1 \mu \mathrm{M}$ sodium azide, and the same inhibitors as shown in $1 \mathrm{E}$. The values shown represent averages based on triplicate samples in a single experiment. Standard deviations were within $10 \%$ of the mean values. The experiment was repeated three times with similar results. 

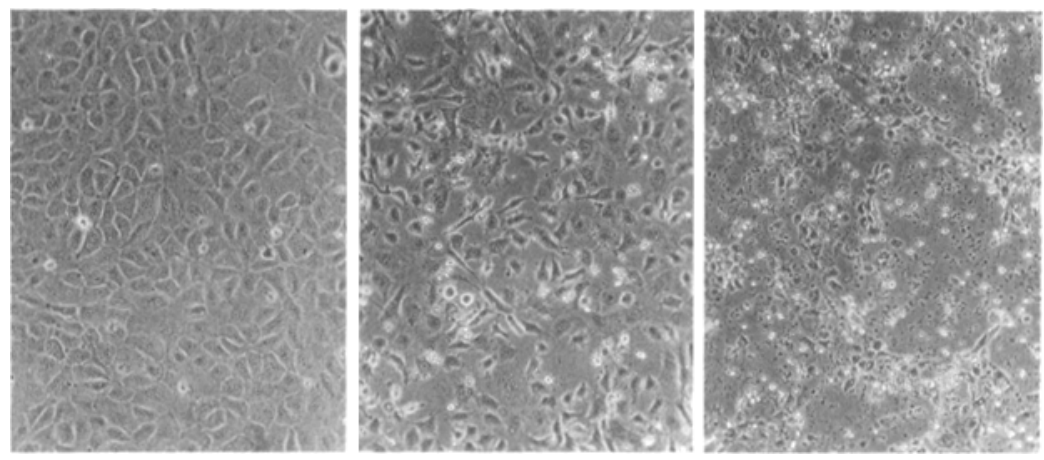

Fig. 5. PMN killing of endothelial cells. The left-hand panel shows an intact monolayer of endothelial cells. The center panel shows a monolayer of endothelial cells $18 \mathrm{~h}$ after treatment with histone-opsonized streptococci and PMNs. The right-hand panel shows a monolayer of endothelial cells $18 \mathrm{~h}$ after treatment with histone-opsonized streptococci and PMNs in the presence of $1 \mu \mathrm{M}$ sodium azide. All photographs $\times 300$.

hydroxyl radicals (HO-) by ferrous iron reduction of $\mathrm{H}_{2} \mathrm{O}_{2}$ and to protect cells from killing by activated PMNs $(28,29,34)$. Under the conditions of the present experiment, these inhibitors blocked by approximately $50 \%$ the killing that occurred in the presence of sodium azide (Figure 4).

\section{DISCUSSION}

PMNs normally circulate within the vasculature as quiescent cells and do not strongly adhere to other cells or injure them. However, upon activation with a variety of agents, PMN adhesiveness is up-regulated and the activated cells produce a series of toxic oxygen metabolites. The activated PMNs also release potent proteolytic enzymes from their storage granules. The oxygen radicals produced by activated PMNs are capable of injuring a variety of cells in culture (28-34) and of producing injury in experimental animals $(35,36)$. Based on the protective effects of $\mathrm{HO}^{\cdot}$ scavengers and iron chelators, $\mathrm{HO} \cdot$ has been implicated as the oxygen metabolite directly responsible for the killing of a variety of target cells in vitro $(28,29,34)$. Myeloperoxidase products of $\mathrm{H}_{2} \mathrm{O}_{2}$ such as hypochlorous and hypobromous acids have also been implicated in cell killing (37).

Leukocyte proteolytic enzymes are also capable of injuring cells in culture under some conditions $(38,39)$. In addition, proteases are thought to be responsible for certain chronic, tissue-desiructive conditions such as emphysema (40). A number of studies have also suggested a role for proteases from leukocytes 
(as well as other sources) in tumor cell invasion and metastasis (41-43). Proteases are thought to cause the breakdown of the stromal tissue surrounding the growing tumor and thereby facilitate the spread of the cancer cells. In a recent study we demonstrated that murine fibrosarcoma cells were capable of injesting opsonized microbial particles (12). The presence of the microbial particles had no effect on the in vitro growth of the tumor cells but greatly enhanced their in vivo growth. More importantly, the malignant cells with intracellular microbial particles also invaded and metastasized more rapidly than untreated tumor cells. Associated with increased tumor growth and spread was an intense inflammatory reaction at the primary tumor site characterized by large numbers of PMNs. In order to begin delineating what role, if any, PMNs might play in facilitating tumor growth and spread, we have examined the interaction of PMNs with the fibrosarcoma cells in vitro.

In the present study it was found that the murine fibrosarcoma cells were highly sensitive to the monolayer-disrupting activity of the PMNs but were very resistant to PMN-mediated killing. Evidence strongly indicates that the monolayer-disrupting activity was protease-mediated. It could be duplicated with extracts of PMNs containing the bulk of the leukocyte proteases, and it could be inhibited with protease inhibitors such as SBTI. The fibrosarcoma cells were much more sensitive to the monolayer-disrupting activity of the PMNs than two other types of nonmalignant cells (endothelial cells and fibroblasts). Malignant cells, in general, are known to be less adhesive than their nonmalignant counterparts, and this is attributable to the fact that malignant cells are defective in fibronectin production $(44,45)$. Fibronectin is one of the extracellular matrix molecules primarily responsible for maintaining cellular adhesion (46).

Although the murine fibrosarcoma cells were more sensitive to disruption of the monolayer by PMNs than were the other two cell types examined, the tumor cells proved to be more resistant to killing than the other cells. Previous studies have shown that killing of both endothelial cells and fibroblasts by PMNs is dependent on $\mathrm{H}_{2} \mathrm{O}_{2}$ production and probably involves the generation of $\mathrm{HO}$. (28, 29, 47). Our past studies have shown further that PMN killing of endothelial celis by oxygen radicals requires close apposition between the target and effector cells (28). What accounts for the relative resistance of the murine fibrosarcoma cells to killing by PMNs is not known. It appears that the antioxidant barrier may be, in part, responsible for this. When sodium azide was added along with the effector cells to the fibrosarcoma cell monolayers, the fibrosarcoma cells were killed. This is not likely to completely explain the differences in sensitivity between the murine fibrosarcoma cells and the endothelial cells, however, because most of the antioxidant activity was provided by the leukocytes themselves.

Another possibility is that the relative resistance of the tumor cells to killing by PMNs is a direct result of their high sensitivity to protease-mediated 
detachment. Perhaps this prevents the maintenance of necessary contacts between effector and target cells required for effective target cell killing by activated PMNs. Additional experiments will need to be done to determine if either of these possibilities is correct. Regardless of mechanism, the relative ease with which tumor cells can be released from their substratum by the action of PMNs, coupled with their insensitivity to PMN-mediated killing, may help to explain why the presence of large numbers of PMNs in the primary tumor (12) is associated with an unfavorable outcome.

\section{REFERENCES}

1. Ginsburg, I., M. N. Sela, A. Morag, Z. Rayid, Z. Duchan, M. Ferne, S. RabinowitzBergner, P. Page-Thomas, P. Davies, P. Nichols, J. Humes, and R. Bonney. 1981. The role of leukocyte factors and cationic polyelectrolytes in the phagocytosis of group A streptococci and Candida albicans by neutrophils, macrophages, fibroblasts and epithelial cells. Modulation by anionic polyelectrolytes in relation to the pathogenesis of chronic inflammation. Inflammation 5:289-312.

2. Ginsberrg, I., N. Mor, M. Resnick, and H. Bercovier. 1986. Polycationic agents facilitate endocytosis of microorganisms by amobae. Eur. $J$. Cell. Biol. 41:130-133.

3. Ginsburg, I., R. Borinski, M. Lahav, K.E. Gillert, S. Falkenberg, M. Winkier, and S. MULLER. 1982. Bacteria and zymozan opsonized with histone, dextran sulfate and polyanethole sulfonate trigger intense chemiluminescence in human blood leukocytes and platelets and in mouse peritoneal macrophages. Modulation by metabolic inhibitors in relation to leukocytebacteria interactions in inflammatory sites. Inflammation 6:343-364.

4. Ginshurg, I., R. Borinski, D. Malamud, F. Struckmayer, and V. Flimetzek. 1985. Chemiluminescence and superoxide generation by leukocytes stimulated by polyelectrolyte-opsonized bacteria. Role of polyarginine, polylysine, polyhistidine, cytochalasins and inflammatory exudates as modulators of the oxygen burst. Inflammation 91:245-271.

5. Ginsiuurg, I., R. Borinski, M. Lahav, Y. Matzner, I. Elliason, P. Christensen, and D. MALAMUUD. 1984. Poly $-\mathrm{L}$-arginine and an $N$-formylated chemotactic peptide act synergistically with lectins and calcium ionophore to induce intense chemiluminescence and superoxide production in luman blood leukocytes. Modulation by metabolic inhibitors, sugars, and polyelectrolytes. Inflammation 8:1-26.

6. GinsBurg, 1., R. BORINSKI, and M. PABST. 1985. NADPH and "cocktails" containing polyarginine reactivate superoxide generation in leukocytes lysed by membrane-damaging agents. Inflammation 9:341-363.

7. LaHAv, M., and I. GinsBurg. 1977. Effect of leukocyte hydrolases on bacteria. $X$ The role played by leukocyte factors, cationic polyelectrolytes, and by membrane-damaging agents in the lysis on Staphylococcus aureus: Relation to chronic inflammatory processes. Inflammation 2:165-177.

8. Ginsburg, I., M. LAHAv, and P. Gresbrecht. 1982. Effect of lenkocyte hydrolases on bacteria. XVI. Activation by leukocyte factors and cationic substances of antolytic wall enzymes in Staphylococcus aureus: Modulation by anionic polyelectrolytes in relation to survival of bacteria in inflammatory exudates. Inflammation 6:269-284.

9. Ginsburg, I., and M. LAHAv. 1983. Cationic polyelectrolytes activate autolytic wall enzymes in Staphylococcus aureus: Modulation by anionic polyelectrolytes in relation to the survival of bacterial constituents in tissues. In The Target of Penicillin Action. Walter de Gruyer, Berlin, 341-346. 
10. Ginsburg, I. 1987. Cationic polyelectrolytes: A new look at their possible roles as opsonins, as stimulators of the respiratory burst in leukocytes, in bacteriolysis and as modulators of immune complex disease. Inflammation 11:489-515.

11. WARren, J. S., P. A. WARD, K. J. Johnson, and I. GinsBurg. 1987. Modulation of acute immune complex-mediated tissue injury by the presence of polygenic substances. Am. J. Pathol. 128:67-78.

12. Ginsburg, I., S. E. G. Fligiel, R. G. Kunkel, B. Riser, and J. Varani. 1987. Phagocytosis of Candida albicans enhances malignant behavior of murine tumor cells. Science 238:15731575.

13. BeCKER, E. L. 1988. The cytotoxic action of neutrophils on mammalian cells in vitro. Prog. Allergy 40:132-208.

14. Bevilacgua, M. P., J. S. Pober, M. E. Wheeler, R. S. Cotran, and M. A. Gimbrone, Jr. 1985. Interleukin 1 acts on cultured human vascular endothelium to increase the adhesion of polymorphonucleat leukocytes, monocytes and telated cell lines. J. Clin. Invest. 76:20032010.

15. Arnaoit, M. A., R. M. Hakin, R. F. Todd, N. Dana, and H. R. Colten. 1985. The gtanulopenia of hemodialysis is associated with increased surface expression of a gratulocyte adheșion-promoting glycoprotein (Mo1). N. Engl. J. Med. 312:457-462.

16. Dishon, T. R. Finkel, Z. Marcus, and I. GinsBurg. 1967. Cell sensitizing products of streptococci. Immanology 13:555-564.

17. Lopatin, D., and R. E. Kessler. 1985. Pretreatment with lipoteichoic acid sensitizes target cells to antibody-dependent cellular cytotoxicity in the presence of anti-lipoteichoic antibodies. Infect. Immun. 48:638-643.

18. Varant, J., F. W. ORR, and P. A. WARD. 1979. Hydrolytic enzyme activities, migratory activity and in vivo growth and metastatic potential of recent tumor isolates. Cancer Res. 39:2376-2380.

19. RYAN, U. S., and L. WhITE. 1986. Microvascular endothelium, isolation with microcarriers. Axterial, venous. J. Tissue Cult. Methods 10:9-13.

20. Phan, S. H., J. VARANI, and D. SMTTH. 1985. Rat lung fibroblast collagen metabolism in bleomycin-induced pulmonary fibrosis. J. Clin. Invest. 76:241-247.

21. Fischer, W., H. V. KACH, and P. HAAS. 1983. Improved preparation of liptoteichoic acids. Eur. J. Biochem. 154:1115-1116.

22. NeEman, N, and I. GinsBurg. 1971. Red cell sensitizing agent of group A streptococci. II. Immunological and immunopathological properties. Israel J. Med. Sci. 8:1807-1816.

23. BABIOR, B. M., R. S. KIPNES, and J, T. CuRnUTTE. 1973. Biological defense mechanisms: The production by leukocytes of superoxide, a potential bacteriocidal agent. J. Clin. Invest. 52:741-747.

24. ThuRMAN, R. G., H. G. LeY, and R. Scholz. 1972. Hepatic microsomal ethanol oxidation: Hydrogen peroxide formation and the role of catalase. Eur. J. Biochem. 25:420-427.

25. ANSON, M. L. 1940. The estimation of pepsin, trypsin, papain and cathepsin with hemoglobin. J. Gen. Physiol. 23:79-86.

26. Lowry, O. H., N. J. Rosebrough, A. L. FarR, and R. J. Randall. 1951. Protein measurement with the Folin phenol reagent. J. Biol. Chem. 193:265-275.

27. Ginsburg, I., S. E. G. Fligiel, P. A. Ward, and J. Varani. 1988. Lipoteichoic acid antilipoteichoic acid complexs induce superoxide generation by human neutrophils. Inflammation $12: 525-548$.

28. Varani, J., S. E. G. Fligiel, G. O. Till, R. G. Kunkel, U. S. Ryan, and P. A. Ward. 1985. Pulmonary endothelial cell killing by human neutrophils. Possible involvement of hydroxyl radical. Lab. Invest. 53:656-663.

29. Gannon, D. E., J. Varani, S. H. Phan, J. H. Ward, J. Kaplan, G. O. TIll, R. H. Simon, U. S. RYAN, and P. A. WARD. 1987. Source of iron in neutrophit-mediated killing of endothelial cells. Lab. Invest. 57:37 444 . 
30. Varan, J., M. J. Bendelow, D. E. Sealey, S. L. Kunkel, D. E. Gannon, U. S. Ryan, and P. A. WARD. 1988. Tumor necrosis factor enhances susceptibility of vascular endothelial cells to neutrophil-mediated killing. Lab. Invest. 59:292-295.

31. SACKs, T., C. F. MOLdOW, P. R. CRADDOCK, T. K. Bowers, and H. S. JACOB. 1978. Oxygen radicals mediate endothelial cell damage by complement-stimulated granulocytes, An in vitro model of immune vascular damage. J. Clin. Invest. 61:1161-1167.

32. Weiss, S. J., J. Young, A. F. LoBuglo, A. SulvkA, N. F. NimEH. 1981. Role of hydrogen peroxide in neutrophil-mediated destruction of cultured endothelial cells. J. Clin. Invest. 68:714-720.

33. MARTIN, W. J. 1984. Neutrophils kill pulmonary endothelial cells by a hydrogen-peroxidedependent pathway. An in vitro model of neutrophil-mediated lung injury. Am. Rev. Respir. Dis. 130:209-213.

34. Starke, P. E., and J. L. Farber. 1985. Ferric iron and superoxide ions are required for the killing of cultured hepatocytes by hydrogen peroxide. Evidence for the participation of hydroxyl radicals formed by an iron-catalyzed Haber-Weiss reaction. J. Biol. Chem. 260:10099-10106.

35. Fligiel, S. E. G., P. A. WaRD, K. J. Johnson, and G. O. TILL. 1984. Evidence for a role of hydroxyl radical in immune complex-induced vasculitis. Am. J. Pathol. 115:397-405.

36. Ward, P. A., G. O. Tild, R. Kunkel, and C. Beauchamp. 1983. Evidence for a tole of hydroxyl radical in complement and neutrophil-dependent tissue injury. J. Clin. Invest. 72:789795.

37. Clarke, R. A., and S. J. Klebanoff. 1975. Neutrophil-mediated tutnor cell toxicity. Role of the peroxidase system. $J$. Exp. Med. 141:1442-1447.

38. Smedley, L. A., M. G. Tonnesen, R. A. Sandhous, C. Haslett, L. A. Guthrie, R. B. JoHNSTON, P. M. HENSON, and G. S. WORTHEN. 1986. Neutrophil-mediated injury to endothelial cells. Enhancement by endotoxin and essential role for neutrophil elastase. J. Clin. Invest. 77:1233-1239.

39. Harlan, J. M., B. R. Schwartz, M. A. Reidy, S. M. Schwartz, H. D. OChs, and L. A. HARKer. 1985. Activated neutrophils disrupt endothelial monolayer integrity by an oxygen radical-independent mechanism. Lab. Invest. 52:141-150.

40. Senior, R. M., H. Tegner, C. Kuhn, K. Ohlsson, B. C. Stascher, and J. A. Piercez. 1977. The induction of pulmonary emphysema with human leukocyte elastase. Am. Rev. Respir. Dis. 116:465-475.

41. Taubman, S. B., and R. B. Cogen. 1975. Cell-detaching activity mediated by an enzyme(s) obtained from human leukocyte granules. Lab. Invest. 32:555-560.

42. GiRALDI, T. C., C. NisI, and G. SAVA. 1977. Lysomal enzyme inhibitors and antimetastatic activity in the mouse. Eur. J. Cancer 13:1321-1323.

43. Petterson, J. 1977. Fibrinolysis and anti-fibrinolytic agents in the growth and spread of tumors. Cancer Treat. Rev. 4:213-217.

44. Alitalo, K., J. Keski-Oja, K. Hedman, and A. Vaheri. 1982. Loss of different pericellular matrix components of rat cells transformed with a $T$-class ts mutant of Rous sarcoma virus. Virology 119:347-357.

45. VAHERT, A., and D. F. MOSHER. 1978. High molecular weight, cell surface-associated glycoprotein (Fibronectin) lost in malignant transformation. Biochim. Biophys. Acta 516:1-9.

46. Yamada, K. M., K. Oolden, and I. PASTAN. 1978. Transformation-sensitive cell surface protein. Isolation, characterization and role in cellular morphology and adhesion. N.Y. Acad. Sci. 312:256-267.

47. Simon, R. H., C. H. SCOGGN, and D. Peterson. 1981. Hydrogen peroxide causes the fatal injury to human fibroblasts exposed to oxygen radicals. J. Biol. Chem. 256:7181-7186. 